\title{
Use of Frozen Silt Mat, an Alternative to Crane Timber Mat to Minimize Energy as Ninth Waste and to Reduce $\mathrm{CO}_{2}$ Emissions
}

\author{
Ghulam Muhammad Ali ${ }^{1, *}$, Habiba Zahir Imam², Sahar Rana', Rafiq Ahmad², Ahmed Bouferguene ${ }^{3}$, and \\ Mohamed Al-Hussein ${ }^{1}$ \\ ${ }^{1}$ Department of Civil and Environmental Engineering, University of Alberta, Edmonton, Canada \\ ${ }^{2}$ Department of Mechanical Engineering, University of Alberta, Edmonton, Canada \\ ${ }^{3}$ Campus Saint-Jean, University of Alberta, Edmonton, Canada \\ gmali@ualberta.ca
}

\begin{abstract}
The fourth revolution in industry is all about process automation, optimization, and intelligence. Energy optimization is one of the critical aspects of Industry 4.0. Energy as the ninth waste in lean manufacturing results in $\mathrm{CO}_{2}$ emissions as a by-product. The practitioners take diverse initiatives to mitigate the impact of $\mathrm{CO}_{2}$ emissions by encouraging energy usage reduction. The impact of $\mathrm{CO}_{2}$ emissions on the environment is a significant concern for the $21^{\text {st }}$ century. Organizations around the world are adopting novel sustainable approaches to minimize energy utilization to lessen the environmental impact. In the same way, modular construction uses lean concepts to minimize the seven wastes and, directly or indirectly, reduces energy utilization. With the advent of modular construction, the application of high-capacity mobile cranes surged. For modular construction activities, the crane industry uses crane mats, usually timber mats, for soil stability underneath the high-capacity mobile cranes. This research encompasses the calculations for the indirect/direct $\mathrm{CO}_{2}$ emissions of timber mat utilization versus a novel application of crane mats prepared of frozen silt. The finite element simulation estimates the equalling of frozen silt against Coastal Douglas-Fir mats, dependable upon construction site ambient temperature constraint. The results show a promising impact of using frozen silt in energy wastage and $\mathrm{CO}_{2}$ emissions reduction.
\end{abstract}

Keywords: Modular Construction, Energy Wastage, $\mathrm{CO}_{2}$ Emissions, Crane Mats, Frozen Silt, Finite Element Analysis

\section{Introduction}

Created in the Japanese car industry, Lean Manufacturing currently remains a leading approach worldwide for industries. It intends to diminish waste and improve value (high quality, low cost, short lead times) [1]. Lean manufacturing experts identified seven types of waste in product development: overproduction, defects, inventory, over-processing, transportation, waiting, and motion. The three instances of Industry 4.0 meeting Lean are continuous improvement, putting customers first, and eradicating waste in the value chain [2]. Therefore, the main objective of lean is customer satisfaction, quality, and responsiveness. However, there has been a growth in customers wanting environmentally sustainable products. Organizations are compelled by customer satisfaction and environmental regulations to re-examine these objectives [3].

Environmental pollution is one of the significant concerns bought forward by the sustainability movement. The crippling impact has put industries on caution to imminent fate if a better move is not made in time [4], [5]. Environmental effects can be considered because of 'green wastes.' Like lean, eight wastes are categorized under green waste: Greenhouse Gases (GHG), Eutrophication, Excessive Resource Usage, Excessive Water Usage, Excessive Power Usage, Pollution, Rubbish and Poor Health \& Safety [6]. In 2015, Canada's total GHG emissions were 722 mega tonnes (Mt) of carbon dioxide equivalent ( $\mathrm{CO}_{2}$ emissions), as shown in Figure 1 [7], [8]. Residential, commercial, and industrial buildings are responsible for 17\% of Canada's GHG emissions [9]. The International Energy Agency (IEA) has highlighted the need for energy efficiency measures to reduce by two-thirds in the energy intensity of the global economy by 2050 [10]. Figure 2, Canada contributes to $2 \%$ of the emissions but has the highest emissions per capita [11].

Many countries are imposing carbon tax as a step towards lowering GHG emissions. Similarly, Ottawa (Canada) declared that each province would require a cost on carbon discharges of $\$ 20$ per ton of emission by January 1, 2019. This cost will increase by $\$ 10$ every year until it reaches $\$ 50 /$ ton in 2022 [12]. Apart from government initiatives, the construction industry has evolved to increase productivity and lower its carbon footprint. The construction industry utilizes approximately $50 \%$ of the natural resources and uses $70 \%$ of wood materials, which results in high levels of $\mathrm{CO}_{2}$ emissions [13]. The 
proposed research methodology substitutes conventional crane matting solutions with frozen silt mat and analyzes its impact on energy utilization and $\mathrm{CO}_{2}$ emissions. The environmental effects of frozen silt mat technology are investigated in this contribution to compare the $\mathrm{CO}_{2}$ emissions between timber mats and frozen silt.

As per the research done by Ali (2018), the work on construction sites in Northwest Canada usually continues for eight months, therefore using frozen silt mat for the shoulder season results in cost savings and energy saving in the form of lower $\mathrm{CO}_{2}$ emissions. The shoulder season is assumed to be approximately one month when the ambient temperature is close to $-10^{\circ} \mathrm{C}$. The mechanical properties of frozen silt mat at $-10^{\circ} \mathrm{C}$ are at par with Coastal DouglasFir [14]. A bottom-up estimate for $\mathrm{CO}_{2}$ emissions sums up to analyze energy wastage, each workday for one month. The results show the promising impact of using frozen silt to reduce $\mathrm{CO}_{2}$ emissions. These calculations can build a foundation for the practical use of frozen silt as a crane mat for modular construction in the cold regions of North America.

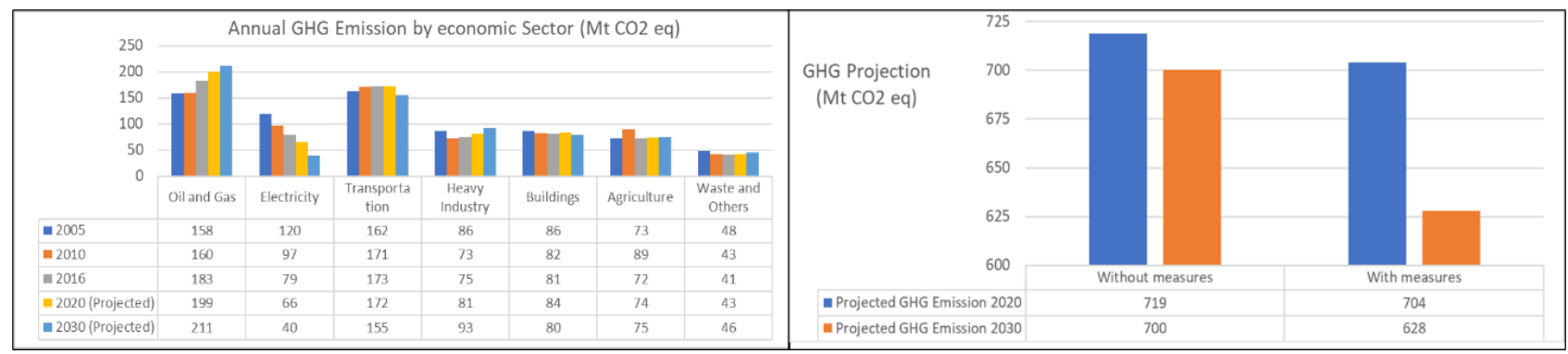

Fig. 1: Canada's Greenhouse Gas Emitting sectors and Estimated Future GHG Emissions. Source: Adapted from Government of Canada, "Canada's greenhouse gas and air pollutant emissions projections.," Gatineau, QC, 2018.

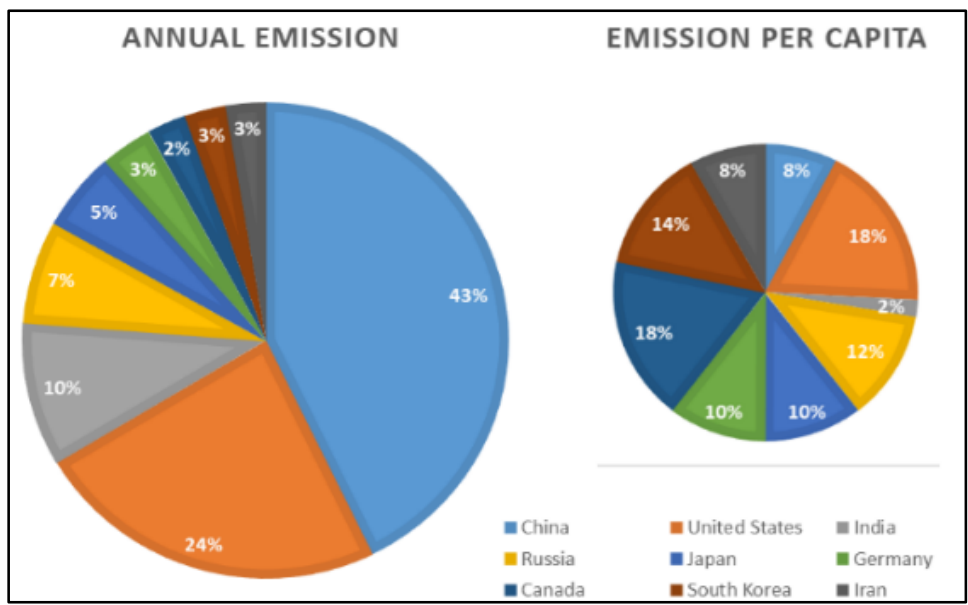

Fig. 2: Annual $\mathrm{CO}_{2}$ Emissions of Nine Major Countries VS per Capita. Source: Adapted from Union of Concerned Scientists, "Each Country's Share of CO2 emissions," 2020. [Online]. Available: https://www.ucsusa.org/resources/each-countrys-share-co2emissions.

\section{Literature Review}

\subsection{Current Construction Methodologies}

There are two main types of construction methodologies: on-site and off-site construction, also known as modular construction. On-site construction involves transporting all disassembled material such as wood/timber, steel, concrete and then framing and structuring those materials at the construction site. Off-site modular construction requires planning, designing, fabricating, and assembling building elements at a separate location away from the actual construction site. The modular method uses lean principles to convert internal processes to external ones and decrease project completion 
time, reducing $\mathrm{CO}_{2}$ emissions. Overall, modular construction decreases the carbon footprint of the construction industry [15]. Al-Hussein, Manrique, \& Mah [15] research indicates that $43 \%$ of $\mathrm{CO}_{2}$ emissions can be reduced by adopting modular construction. A relative comparison was conducted by Al-Hussein, Manrique, \& Mah [15] using the construction of a residential building where both methodologies were employed and analyzed. This study showed that on-site construction produces 431 Metric tons of $\mathrm{CO}_{2}$ emissions, whereas modular construction (off-site construction) produces only 247.23 Metric tons of $\mathrm{CO}_{2}$ emissions (see Figure 3), with a $42 \%$ reduction. The adoption of modular construction also decreased project completion time from 10.8 months to 6.5 months [15].

Seo, Kim, Hong, \& Kim [16] evaluated the impact of the material production, material transportation, and construction phases from a construction site perspective. In addition, $\mathrm{CO}_{2}$ emissions were examined by Seo, Kim, Hong, \& Kim [16] through the system capacity and gross floor area for each work type. Calculations showed that $\mathrm{CO}_{2}$ emissions from the material production phase constitute $93.4 \%$ of $\mathrm{CO}_{2}$ emissions [16]. $\mathrm{CO}_{2}$ emissions from material transportation and on-site construction account for $2.4 \%$ and $4.2 \%$ of the total $\mathrm{CO}_{2}$ emissions, respectively. The research concluded that selecting appropriate input materials and resources was vital to reducing $\mathrm{CO}_{2}$ emissions [16]. The life cycle of buildings is usually divided into the production of materials, transportation of materials, construction phase, operational and maintenance phase, and dismantling and disposal phase. All these phases contribute to different levels of $\mathrm{CO}_{2}$ emissions. While there are six types of main factors contributing to global warming $\left(\mathrm{CO}_{2}, \mathrm{CH}_{4}, \mathrm{~N}_{2} \mathrm{O}, \mathrm{HFCS}\right.$, PFCS, and $\left.\mathrm{SF}_{6}\right)$, as defined in the United Nations Framework Convention on Climate Change, the subject of this study is the calculation of $\mathrm{CO}_{2}$ emissions [23]. The research showed that concrete works account for a high level of $\mathrm{CO} 2$ emissions in the material production phase (see Figure 3), of 1,011.3 Tons of $\mathrm{CO}_{2}$ emissions [16]. In the material transportation phase, the $\mathrm{CO}_{2}$ emissions equal $107.7 \mathrm{Tons}$ of $\mathrm{CO}_{2}$ emissions, which makes up $2.4 \%$ of the total $\mathrm{CO}_{2}$ emissions [16].
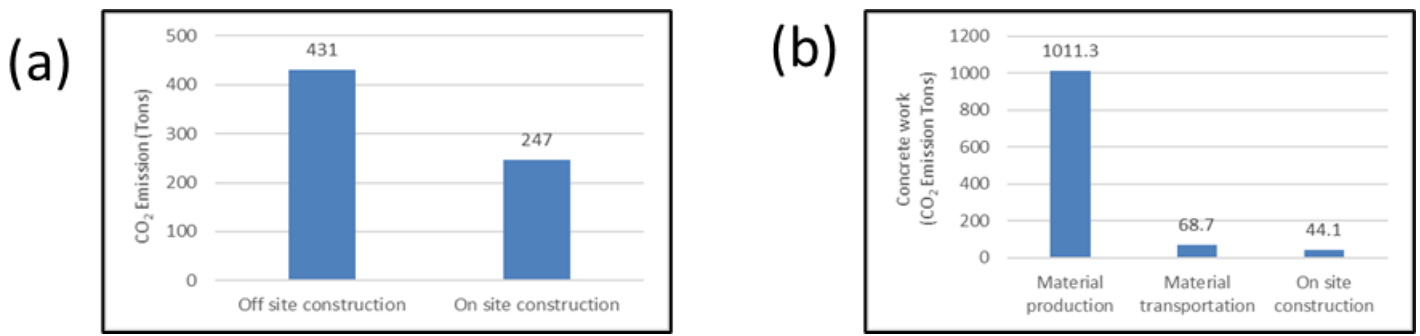

Fig. 3(a): Difference in Energy Released During On-Site and Off-Site Construction: Adapted from M. Al-Hussein, J. D. Manrique and

D. Mah, "North Ridge CO2 Analysis Report Comparison between Modular and On-Site Construction," Edmonton, 2009. [15], (b):

Construction Process Energy Waste: Adapted from M.-S. Seo, T. Kim, G. Hong and H. Kim, "On-Site Measurements of CO2 emissions during the Construction Phase of a Building Complex," Energies, vol. 9, no. 599, pp. 1-13, 2016 [16].

\subsection{Construction Equipment}

One of the most common types of equipment used on construction sites is a mobile crane. The ground pressure developed by a crane can be very high, and its track/outrigger generates significant pressure on the ground surface. Many soils and locations on a job site cannot withstand high equipment pressure without soil failure, which can cause a crane to topple over. Currently, the two most common cranes mats used in Canada are Coastal Douglas-Fir timber mats and steel mats [17]. Excessive energy is used to produce and transport these mats to construction sites [18]. The research methodology outlined in this contribution will discuss how to reduce $\mathrm{CO}_{2}$ emissions released in the production and transportation of timber mats with a more energy-saving solution such as frozen silts, a substitute conventional crane matting solution, and analyze its impact on $\mathrm{CO}_{2}$ emissions using a hypothetical case study. The environmental impact of frozen silt mat technology will be analyzed to compare the $\mathrm{CO}_{2}$ emissions between timber mats and frozen silt mats under extreme weather conditions.

\subsection{Frozen Silt as Crane Mat Material}

The construction industry relies upon using cranes to build the structures needed. With the advent of off-site construction as the cost-effective solution for the construction industry automation, complete projects are delivered to the construction site in the form of modules, which have become heavier over the years due to the increasing number of parts combined and 
joined together. As a result, high-capacity cranes became the backbone for the assembly/installation of modularized plants/structures. Since the weight of the lifting system (crane and payload) has become heavier, ignoring the allowable bearing capacity under the crawler crane tracks/outriggers by the practitioners can lead to the ground's failure, resulting loss of life and property. The traditional norms to raise the soil bearing capacity proceeds in two phases: ground a layer (or a mix of layers) of construction aggregates compacted, and/or addition of timber mats (1, 2, or 3 layers of mats). With the adoption of the modular construction paradigm, the demand for crane mats augmented. As a result, the cost drivers associated with the stacking and transportation of timber mats to and from the construction site also surged. However, the production of these mats remained the same or increased a little. According to a market research report published in 2014, the mat demand in Canada annually is around 450,000 to 750,000 [17]. The production of these mats in Canada is only about 20,000 to 25,000 per year. Even the production in North America is not more than 600,000 per year. (see Figure 4). The growth of the mat industry is about 200\% from 2009 to 2014 [17].

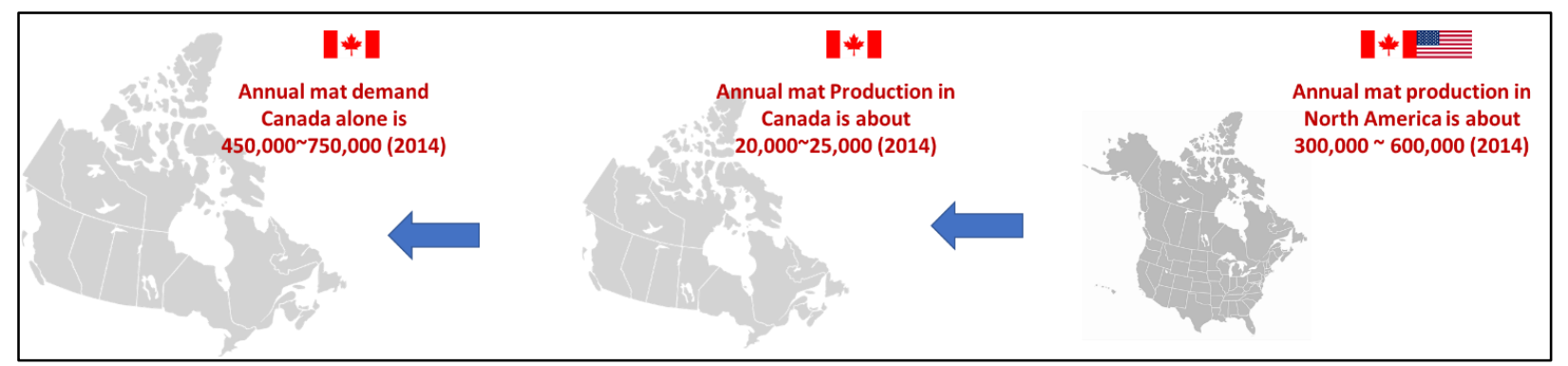

Fig. 4: Mat demand and supply gap for Canada. Adapted from Golden Environmental Mat Services, "2014 ACCESS MAT RESEARCH: PERSPECTIVES ABOUT THE INDUSTRY AND ASSET TRACKING CONCEPT,” Calgary, 2015.

Ali [18] conducted research to show that frozen silt has properties similar to the supporting structural material wood [14], [18]. Considering the mechanical properties of frozen silt (a frozen mixture of water and silt), the uniqueness of using it as crane matting is a novel idea that transcends traditional constraints and helps minimize environmental impact. The mechanical properties of frozen silt are comparable to timber matting (Coastal Douglas-fir) but are dependent upon the temperature constraint (i.e., the mechanical properties of frozen silt with the temperature at/below $-10^{\circ} \mathrm{C}$ are comparable to Coastal Douglas-Fir) [3]. For the finite element analysis, the study used a standard size mat. The competitive analysis was established by Ali [18] on the traditional selection criteria of the crane mat, which is the compressive stress transferred to the ground. The required mat surface temperature for frozen silt was $-10^{\circ} \mathrm{C}$ for the analysis, based on its practical usage and finite element simulation (see Table 1).

Table 1: Linear mechanical properties for comparison

\begin{tabular}{|c|l|c|c|c|}
\hline & & Units & Coastal Douglas-Fir & Frozen silt \\
\hline 1 & Young's Modulus & $\mathrm{MPa}$ & $13,400[19]$ & $10,000[20],[21]$ \\
\hline 2 & Poisson's Ratio & & $0.449[22]$ & $0.3[3]$ \\
\hline 3 & Tensile Yield Strength & $\mathrm{MPa}$ & $2.3[19]$ & $5.1[21]$ \\
\hline 4 & Compressive Yield Strength & $\mathrm{MPa}$ & $5.0[19]$ & $5.0[21]$ \\
\hline 5 & Tensile Ultimate Strength & $\mathrm{MPa}$ & $5.0[19]$ & $5.1[21]$ \\
\hline
\end{tabular}

The authors of this contribution performed the finite element simulation under similar boundary conditions as of work conducted by Ali [18]. The outcome in stress maps provided a promising approach for using frozen silt as an alternative to Coastal Douglas-Fir. The results show that the crane mats made of frozen silt and Coastal Douglas-Fir are similar in behavior within the constraint of compressive stress distribution (see Figure 5). The compressive stress under the crawler crane track front (left and right) for Coastal Douglas Fir is close to frozen silt, under similar boundary 
conditions, while the superstructure slew from left front to left side. That is why the stress value increases for the left front as the superstructure slew from the left front $\left(0^{\circ}\right)$ to the left side $\left(90^{\circ}\right)$. The stress value is maximum when the crane boom is directly over the crawler track. This phenomenon is due to the change of ground bearing pressure under the crawler track due to superstructure slew [23]. The findings build a strong foundation for using frozen silt mats to alternative timber mats (Coastal Douglas-Fir). Based on the outcome, the bottom-up estimation of capital and operating costs of frozen silt mat can be generated [18].

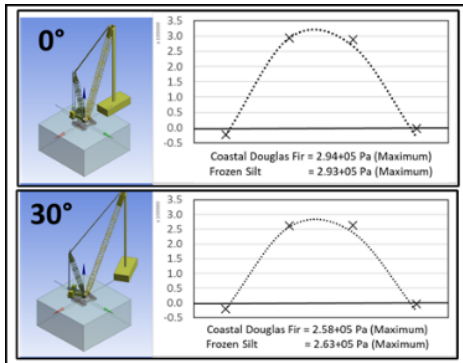

(a) Left Front

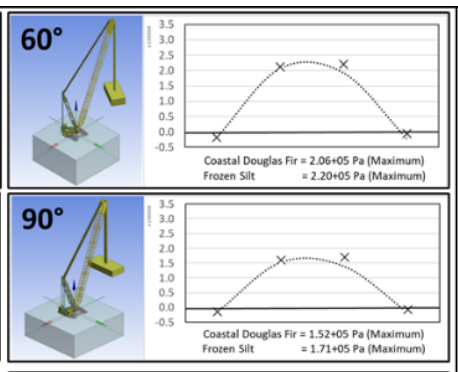

\begin{tabular}{|lll}
\hline Legends: Coastal Douglas Fir $\cdots . . .$. & Frozen Silt $\times$ \\
\hline
\end{tabular}

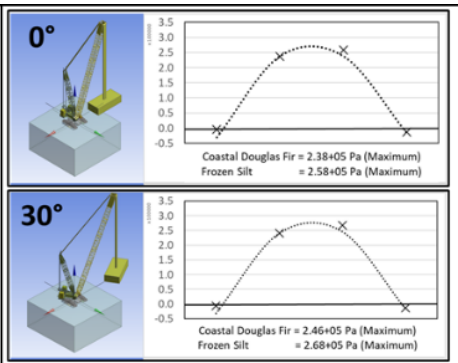

(b) Left Rear

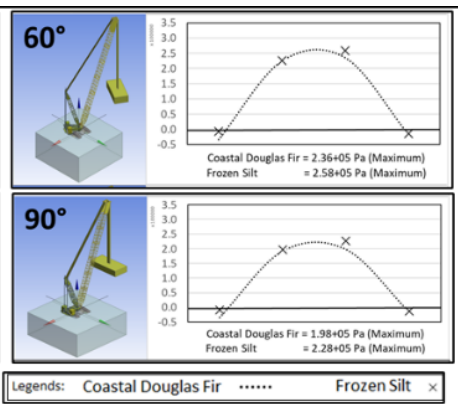

Legends: Coastal Douglas Fir ….... Frozen Silt $x$

Fig. 5: Compressive Stress values under crawler tracks (a): Left Front, (b): Left Rear.

\section{3. $\mathrm{CO}_{2}$ Emissions Calculations}

One of the indicators to measure $\mathrm{CO}_{2}$ emissions is to measure the wastage of energy resources. In terms of frozen silt mats, the environmental impact is to reduce $\mathrm{CO}_{2}$ emissions. The target is to introduce new methods to minimize the construction industry wastes, to make it more efficient and productive. The authors of this contribution initiate the comparison between timber mat usage and frozen silt mat usage. For comparison, a hypothetical project is assumed at Yellowknife (Northwest Territories, north of Alberta, Canada). The main ingredient of frozen silt is silt (soil), and ambient temperature of $-10^{\circ} \mathrm{C}$. Figure 6 shows, about 7.5 months in one year, the average temperature is below freezing [24]. Based on these values, the assumption is that the hypothetical project is located close to Yellowknife. The project's duration (assumed) is one month, i.e., within shoulder season (October, November, April, and May) because the average temperature is below $-10^{\circ} \mathrm{C}$. These months lie on the shoulder season, which means work continues as the temperature is bearable for the workers on site. The total number of days below $-10^{\circ} \mathrm{C}$ is about 44.5 (see Figure 6), available during the shoulder seasons of October, November, April, and May. For the hypothetical project, the crane assumption is Manitowoc 18000, a crawler crane, which requires eight timber mats $(3.6449 \mathrm{~m} \times 2.4384 \mathrm{~m} \times 0.2032 \mathrm{~m}), 4$ for each crane track, and in the case of frozen silt mats, it requires two frozen silt mats $(14.58 \mathrm{~m} \times 2.4384 \mathrm{~m} \times 0.2032 \mathrm{~m})$ (see Figure 7). The lifespan of timber mats is three years (maximum) [14]. The total volume of 8 timber mats is $14.448 \mathrm{~m}^{3}$. The density of Coastal Douglas-Fir is about 0.52997 Metric Ton $/ \mathrm{m}^{3}$ [25]. Based on this density, the weight of these mats is 7.657 Metric Tons. The first thing is to calculate the $\mathrm{CO}_{2}$ emissions during timber manufacturing. Equation (1) proposed by Bergman et al. [13] can be used to calculate the $\mathrm{CO}_{2}$ emissions in metric tons, which is equal to 0.7272 of wood weight in metric tons.

$$
\mathrm{CO}_{2}(\text { Manufacturing })=0.7272 \times W_{g}
$$

One of the significant indirect CO2 emissions (Metric Tons) is transportation from the forest to the manufacturing plant and the manufacturing plant to the crane yard as the final product. Equation (2), proposed by Whittaker et al. [26], can be used by the practitioners for the calculations.

$$
\mathrm{CO}_{2}(\text { transport })=0.032 \times W_{g} \times\left(D_{m}+D_{y}\right)
$$

Where $W_{g}=$ weight of the wood (Metric Tons), $D_{m}=$ distance traveled from forest to manufacturing, and $D_{y}=$ distance from manufacturing to the crane yard. As Coastal Douglas-Fir is readily available in Canada in the form of raw material, the 
average distance for the raw/finished product travel is about $500 \mathrm{Km}\left(D_{m}+D_{y}\right)$ (assumption). Based on these values, the total $\mathrm{CO}_{2}$ emissions are about 0.1225 Metric Ton.

The assumption is that the practitioners use the frozen silt mat for crane lifting on the construction site for one (30 days in total) in one year. The requirement is to calculate the $\mathrm{CO}_{2}$ emissions for one month of timber mat usage. The span of timber mat is three years maximum. If only timber mats are used on the construction site, they last for eight per year [14]. Based on these constraints, the practitioners can calculate the $\mathrm{CO}_{2}$ emissions (Metric Tons) for one month (30 days in total) using the equation (3). The approach is to compare one-month utilization of timber mats and frozen silt mats to calculate $\mathrm{CO}_{2}$ emissions.

$$
\text { Indirect } \mathrm{CO}_{2}=\left(\frac{\mathrm{CO}_{2}(\text { Manufacturing })+\mathrm{CO}_{2}(\text { transport })}{8 \times 3}\right) \times n
$$

Where $n=$ number of months for timber mat usage, in the case of frozen silt mats usage, $n=1$. The indirect $\mathrm{CO}_{2}$ emissions are about 0.237 Metric Ton. For direct $\mathrm{CO}_{2}$ emissions, the authors of this contribution assumed the crane yard in Edmonton, Alberta, Canada, and the distance between Edmonton (Alberta, Canada) and Yellowknife (Northwest Territories, Canada) is about $1,452 \mathrm{Km}$. The total traveling distance for timber mats is about 2,904 Km. Equation (2), in a modified form as equation (3), can be used for the calculation of direct $\mathrm{CO}_{2}$ emissions (Metric Tons) [26].

$$
\mathrm{CO}_{2}(\text { transport })=0.032 \times W_{g} \times D_{l}
$$

Where $D_{l}=$ total distance traveled from yard to site and from site to the yard, the direct $\mathrm{CO}_{2}$ emissions is about 0.122 Metric Ton for 1,452 Km and 7.657 Metric Tons (wood weight). The total $\mathrm{CO}_{2}$ emissions for timber mats for one project and one month is about 0.949 Metric Ton (indirect + direct $\mathrm{CO}_{2}$ emissions). In the case of frozen silt mat, the essential ingredient is soil/silt and $-10^{\circ} \mathrm{C}$. These ingredients are readily available on-site during shoulder season and free of cost. The $\mathrm{CO}_{2}$ emissions for frozen silt will be negligible, i.e., zero for the frozen silt mats (see Table 2).

Table 2: $\mathrm{CO}_{2}$ emissions Calculations

\begin{tabular}{|c|l|c|c|}
\hline & & Timber Mats & Frozen Silt Mats \\
\hline 1 & Indirect $\mathrm{CO}_{2}$ emissions & 0.237 Metric Tons & 0 \\
\hline 2 & Direct $\mathrm{CO}_{2}$ emissions & 0.712 Metric Tons & 0 \\
\hline 3 & Labor and Equipment on Site $\mathrm{CO}_{2}$ emissions & \multicolumn{2}{|c|}{ Assumed same for both } \\
\hline 4 & Total $\mathrm{CO}_{2}$ emissions & 0.949 Metric Ton & 0 \\
\hline
\end{tabular}

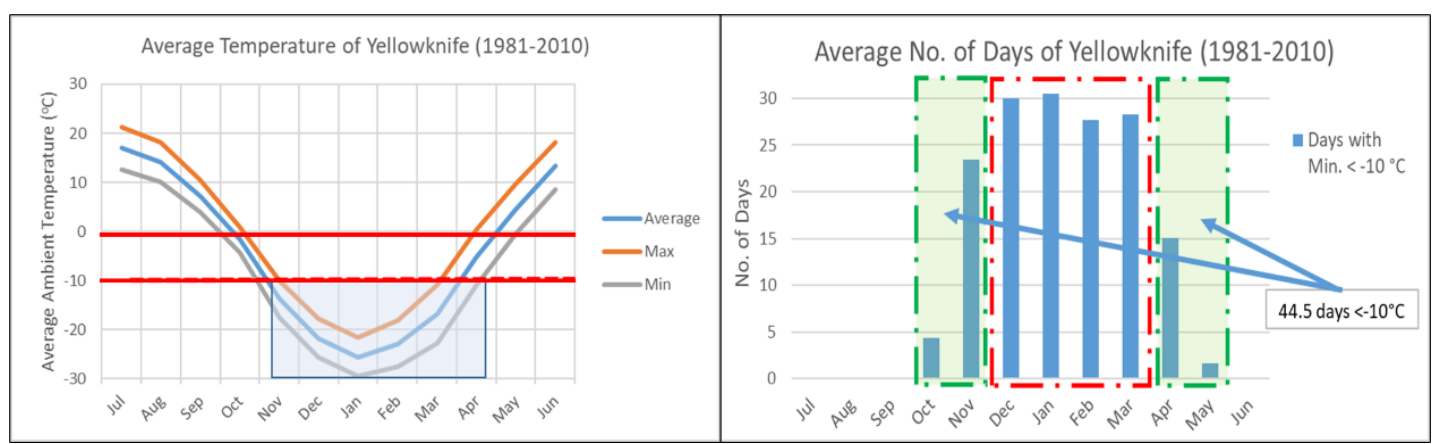

Fig. 6 (a): Average temperature of Yellowknife (b): No of days with ambient temperature below $-10^{\circ} \mathrm{C}$ at Yellowknife. Data from Government of Canada, "Canadian Climate Normals," 2021. [Online]. Available: https://climate.weather.gc.ca/climate_normals/. 


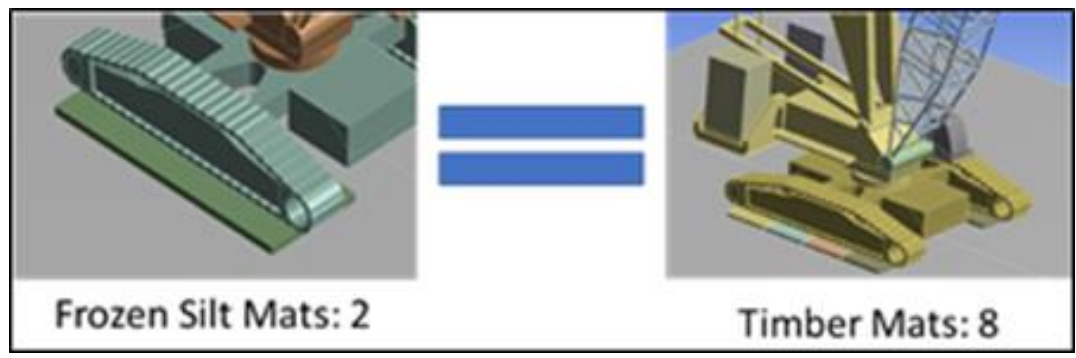

Fig. 7: Timber mats requirement VS Frozen Silt Mats.

\section{Conclusion}

The calculations state that about 0.949 Metric Ton of $\mathrm{CO}_{2}$ emissions can be saved by using the novel approach of frozen silt mat in cold regions of North America instead of using Timber mats. For the calculations for energy wastage, one Metric Ton of $\mathrm{CO}_{2}$ emissions is equal to $1,414.43 \mathrm{KWh}$ or 112.53 gallons of gasoline [27]. Using a similar conversion, the 0.949 Metric Ton (see Table 2) of $\mathrm{CO}_{2}$ emissions means 1,342.30 KWh of energy is saved using frozen silt mats, or 106.79 gallons of gasoline. The research conducted in this contribution concludes that using frozen silt mat can reduce energy wastage.

\section{Future Aspects and Recommendations}

This contribution is restricted to the climate of Yellowknife (Northwest Territories, Canada), more precisely, the weather of North America. The behavior of this novel approach under different climate conditions needs investigation using finite element analysis and actual lab/site testing. For this research, the site activities are considered negligible, but for future research aspects, this needs to be investigated in detail to incorporate the energy cost drivers in detail. In addition to the current research, different project scenarios need to be explored in the future to define the actual requirement. Additional research is required to investigate the usage of frozen silt mats compared to steel mats or plastic mats on construction sites, in direct and indirect $\mathrm{CO}_{2}$ emissions, which leads to energy wastage, as ninth waste.

\section{References}

[1] Jostein Pettersen, "Defining lean production: some conceptual and practical issues.," TQM J., vol. 21, no. 2, pp. 127142, 2009, DOI: 10.1108/17542730910938137.

[2] SAGE Automation, "The new lean: how lean manufacturing meets industry 4.0," 2019. [Online]. Available: https://www.sageautomation.com/blog/the-new-lean-how-lean-manufacturing-meets-industry-4.0. [Accessed: 02-Sep2021].

[3] O. B. Andersland and B. Ladanyi, Frozen Ground Engineering, 2nd Edition, 2nd ed. American Society of Civil Engineers and John Wiley \& Sons, 2003.

[4] S. Jituri, B. Fleck, and R. Ahmad, "A methodology to satisfy key performance indicators for successful ERP implementation in small and medium enterprises," Int. J. Innov. Manag. Technol., vol. 9, no. 2, pp. 79-84, 2018, doi: doi: 10.18178/ijimt.2018.9.2.792.

[5] S. Jituri, B. Fleck, and R. Ahmad, "Lean OR ERP - A Decision Support System to Satisfy Business Objectives," Procedia CIRP, vol. 70, pp. 422-427, 2018, DOI: https://doi.org/10.1016/j.procir.2018.02.048.

[6] J. A. Garza-Reyes, "Lean and green - a systematic review of the state of the art literature," J. Clean. Prod., vol. 102, pp. 18-29, 2015, DOI: https://doi.org/10.1016/j.jclepro.2015.04.064.

[7] Government of Canada, "Canada's greenhouse gas and air pollutant emissions projections.," Gatineau, QC, 2018.

[8] The Canadian Press, "Canada's greenhouse gas emissions," $C B C, 2014 . \quad$ [Online]. Available: https://www.cbc.ca/news/politics/canada-s-greenhouse-gas-emissions-1.2791282. [Accessed: 02-Sep-2021].

[9] L. Koskela, T. Bølviken, and J. Rooke, "Which are the wastes of construction?," 2013.

[10] F. Apostolos, P. Alexios, P. Georgios, S. Panagiotis, and C. George, "Energy Efficiency of Manufacturing Processes: A Critical Review," Procedia CIRP, vol. 7, pp. 628-633, 2013, DOI: https://doi.org/10.1016/j.procir.2013.06.044.

[11] Union of Concerned Scientists, "Each Country's Share of CO2 Emissions," 2020. [Online]. Available: 
https://www.ucsusa.org/resources/each-countrys-share-co2-emissions. [Accessed: 02-Sep-2021].

[12] M. Rabson, "Ottawa to return $90 \%$ of money it collects from carbon tax to the Canadians who pay it," Financial Post, 2018. [Online]. Available: https://financialpost.com/commodities/energy/trudeau-says-will-be-cash-back-from-federalcarbon-tax-in-provinces-without-levy. [Accessed: 02-Sep-2021].

[13] R. Bergman, M. Puettmann, A. Taylor, and K. E. Skog, "The Carbon Impacts of Wood Products," For. Prod. J., vol. 64, no. 7-8, pp. 220-231, Dec. 2014, DOI: 10.13073/FPJ-D-14-00047.

[14] A. G. Muhammad, K. Joe, B. Ahmed, and A.-H. Mohamed, "Competitive Assessment of Ice and Frozen Silt Mat for Crane Ground Support Using Finite-Element Analysis," J. Constr. Eng. Manag., vol. 147, no. 6, p. 4021038, Jun. 2021, DOI: $10.1061 /(A S C E) C O .1943-7862.0002046$.

[15] M. Al-Hussein, J. D. Manrique, and D. Mah, "North Ridge CO2 analysis report: comparison between modular and onsite construction," Univ. Alberta Edmontom, AB, Canada, 2009.

[16] M.-S. Seo, T. Kim, G. Hong, and H. Kim, "On-Site Measurements of CO2 Emissions during the Construction Phase of a Building Complex," Energies, vol. 9, no. 8, 2016, doi: 10.3390/en9080599.

[17] Golden Environmental Mat Services, "2014 ACCESS MAT RESEARCH: PERSPECTIVES ABOUT THE INDUSTRY AND ASSET TRACKING CONCEPT,” Calgary, 2015.

[18] G. M. Ali, "Competitive Analysis and Value Proposition of Frozen Silt Mats as an alternative to Crane Timber Mats," University of Alberta, 2018.

[19] D. E. Kretschmann, "Mechanical Properties of Wood Chapter-5," in Wood Handbook2, U.S. Dept. of Agriculture, Forest Service, Forest Products Laboratory, 10AD, pp. 5.1-46.

[20] C. Ralph. Wilson, "Dynamic properties of naturally frozen Fairbanks silt," Oregon State University, 1982.

[21] Z. J. Yang, B. Still, and X. Ge, "Mechanical properties of seasonally frozen and permafrost soils at high strain rate," Cold Reg. Sci. Technol., vol. 113, pp. 12-19, 2015.

[22] D. W. Green, J. E. Winandy, and D. E. Kretschmann, "Mechanical Properties of Wood," in Wood Handbook, U.S. Dept. of Agriculture, Forest Service, Forest Products Laboratory, 1999, pp. 4.1-45.

[23] J. Shapiro and L. Shapiro, Cranes and derricks, 4th ed. McGraw-Hill Professional, 2010.

[24] Government of Canada, "Canadian Climate Normals," 2021. [Online]. Available: https://climate.weather.gc.ca/climate_normals/. [Accessed: 04-Sep-2021].

[25] SImetric.co.uk, "Wood - seasoned \& dry," 2011. [Online]. Available: https://www.simetric.co.uk/si_wood.htm. [Accessed: 04-Sep-2021].

[26] C. L. Whittaker, N. D. Mortimer, and R. W. Matthews, "Understanding the carbon footprint of timber transport in the united kingdom," in North Energy Associates Limited and Forest Research for the Confederation of Forest Industries (UK) Ltd on behalf of the Timber Transport Forum, 2010.

[27] EPA, "Greenhouse Gases Equivalencies Calculator - Calculations and References," U.S. Environmental Protection Agency, 2021. [Online]. Available: https://www.epa.gov/energy/greenhouse-gases-equivalencies-calculatorcalculations-and-references. [Accessed: 04-Sep-2021]. 